\title{
The Information and Communications Technology in Higher Education: A YouTube Channel as a Resource
}

\author{
Castellar Carlos ${ }^{1 *}$ \\ Quintas Alejandro M. ${ }^{2}$ \\ Pradas Francisco ${ }^{3}$ \\ 1,2,3University of Zaragoza, Calle Valentín Carderera, 4, 22003 Huesca, Spain
}

Keywords: information technologies and communication, university education, video analysis, teaching intervention

\begin{abstract}
The information technologies and communication (ICT) are part of methodological change in university teaching within the framework of the European Higher Education Area. One of the most used ICT within observational of fitness activity-sports are the video analysis techniques. In this regard, free software and free access program on line are sustainable tool for teaching university. This research to implementing the video analysis technology in physical education for primary education classes, with the objective of improve teaching intervention processes. The creation of a YouTube private cannel, the use of video editors and video download on line, or the use of apps for mobile devices in processes evaluation, they are elements to complete the research. $84.3 \%$ of students said that the experience has been useful. $41.2 \%$ did not know edit videos and after the experience itself. 85.3\% prefer not to perform this kind of task instead written work.
\end{abstract}

\section{Introduction}

The European Higher Education Area (EHEA), since the Bologna Declaration in 1999, has provided a framework for action where ICTs play an important role in the contribution of the paradigm shift. They seek a treatment of the contents that allow students to face the new challenges of society, through adequate digital literacy (Esteve \& Gisbert, 2011).

Today the digital competence is part of the teaching competencies that characterize the professional profile of the university professor. However, it is necessary to determine three different aspects in this profile (Carrera \& Coiduras, 2012).

I. The level of this competence in teachers

II. Your willingness to contemplate it in the subjects taught

III. And the identification of training needs that they have in competition.

Other authors have also linked teaching of university quality with the appropriate didactic management and use of ICTs (Cebrián, 2006; Zabalza, 2007; Ríos

*E-mail: castella@unizar.es, phone: +34-974292727 
\& Ruiz, 2011). In words of Zabalza (2003), "to innovate is not to do different things, but to improve". Probably, what one of the most important authors who work on the subject of university teacher teaching competencies pretends to be, is that the change in ICT is not enough to determine their pedagogical capacity, but their methodological treatment is what the Become instructional tools of great potential.

The observation as a method, both teaching and applied to research, has been widely used and studied in the field of sports skills (Argilaga \& Anguera, 1999; Anguera, 2004; Medina \& Delgado, 2010; Argilaga, Villaseñor, Mendo, \& López, 2011). In fact, the techniques of analysis in observational studies in the sports sciences have been one of the most rigorous research methods and have most supported our area of work, obtaining a greater recognition of other sciences (Anguera \& Hernández-Mendo, 2015).

The free and free software is a tool that makes it possible to use it (both in education and in the field of sports performance) with no borders other than those drawn by the adaptation or not to the type of analysis that is needed. Different studies have addressed this issue, highlighting the need and usefulness of these tools (Mariño, 2006; Adell \& Bernabé, 2007; García \& Cuello, 2007; Chavarría, 2011; Pradas, Bataller \& Castellar, 2011).

Youtube $^{\circledR}$, the most popular video channel on the net, can also have important educational potential. In spite of finding some studies that analyze its usefulness in the educational field (Castañeda, 2009; Salinas, 2012), no studies have been found that try their usefulness in the field of the education of the physical education and the educational intervention in education higher.

The main objective of this experience is to use active methodologies for the analysis of teacher intervention in the classroom from the treatment and observation of videos in network with the program YouTube.

\section{Material and methods}

It is a descriptive design based on indirect observation. The didactic design to be used will be participatory (mainly due to the characteristics of the tool and the objectives of teacher innovation). It begins with a session of master nature where the objective is presented with the group-class, describes the tools to be used and the procedure that will be carried out after the registration of images of each teaching intervention.

The participant sample is formed by the students of the annual core subject (10 ECTS) of "Physical Education in Primary Education". Participants will participate in the course (continuous evaluation) in the Faculty of Human Sciences and Education in Huesca and in the Faculty of Education of Zaragoza (Table 1).

Table 1. Participant sample

\begin{tabular}{llcr}
\hline & $\begin{array}{l}\text { Faculty of Human Sciences and } \\
\text { Education in Huesca }\end{array}$ & Faculty of Education of Zaragoza \\
\hline sample size & $\mathrm{n}=58$ & $\mathrm{n}=64$ & \\
& & & Total sample: 122 students \\
\hline
\end{tabular}


Following the guidelines of Area-Moreira, Hernández-Rivero and Sosa-Alonso (2016), the didactic integration model of ICT in the classroom has been followed. That is, ICTs do not displace or replace traditional materials, but complement each other.

The main instrument for collecting information from teacher intervention sessions is an un-validated ad hoc form used in the sessions of the "Teaching in Physical and Sports Activities", adapted for the context of physical education in primary education and To the objective of the investigation.

Once the tool for analysing teacher intervention is defined and described, the process to be followed is defined as follows (Figure 1):

I. Creation of a Gmail account of each student.

II. Creation of a channel on YouTube: created by the teacher and proceeds to the invitation of his students so they can upload and download videos, as well as make their contributions in the discussion forum in text and video format.

III. Explanation of the video editor Active Presenter for the production of videos in short format (maximum 2 minutes) where the student expresses his impressions about the teacher intervention in a justified way.

IV. Description of the operation of the tool for downloading video on YouTube online (without downloading any program).

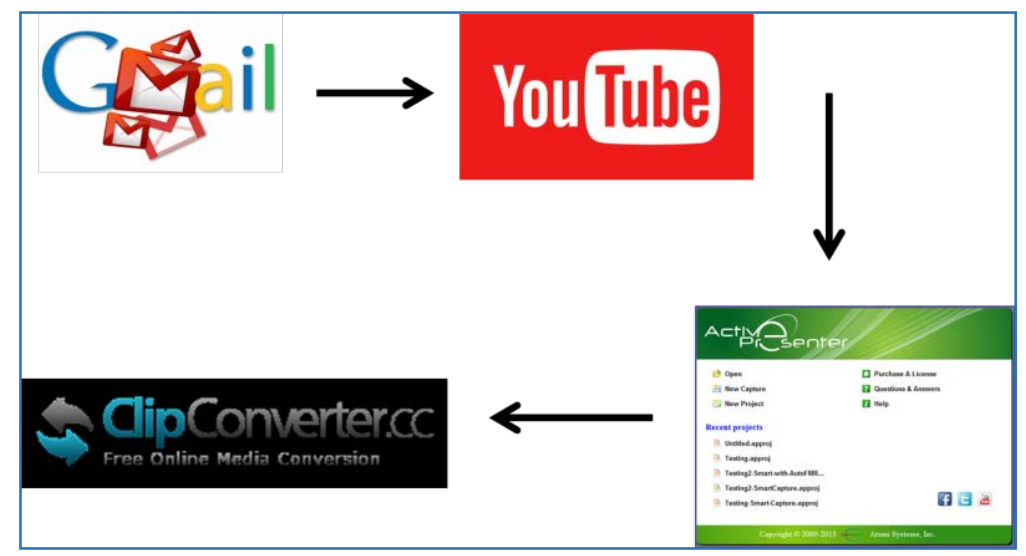

Figure 1. Sequencing of the presentation of tools and programs necessary to initiate the didactic process

Mobile applications are used as an instrument for data collection (Santiago, 2014). This is done through the Socrative (C) application for mobile devices or smartphone. The validated REATIC questionnaire is applied for the analysis of learning styles and ICT in the personal training of university students (De Moya, Hernández, Hernández, \& Cózar, 2011).

The students participating in the experience gave their consent for the transfer of images for pedagogical and didactic purposes.

The didactic sequence that configures the work plan is articulated in these steps:

I. A student directs a pre-designed physical education practice session (in the context of primary education) to the rest of the class group.

II. The class is recorded from the observation laboratory of the sports hall of 
the Faculty.

III. Delivery to the student who directed the session of the corresponding video on a USB storage device.

IV. The student uploads the YouTube channel created the session, denominating it with a code.

$\mathrm{V}$. In groups of three students, they make a revision of the elements related to the teaching intervention (treated in the classroom in master sessions), using the template created for this purpose. Once completed, they make a video (maximum 2 minutes in length) and upload it to the YouTube channel.

VI. The student who directed the session makes a written reflection after their experience, the teacher's comments and the reflections of the students in video format. This is given to the teacher as evidence to be qualified.

The timing of the work plan is reflected in the following table (Table 2).

Table 2. Timing of the work plan

\begin{tabular}{ccccc}
\hline Task 1 & Task 2 & Task 3 & Task 4 & Task 5 \\
\hline $\begin{array}{c}\text { Recording of } \\
\text { the student-led } \\
\text { session }\end{array}$ & $\begin{array}{c}\text { Deliver the } \\
\text { student the } \\
\text { video session in } \\
\text { a USB storage } \\
\text { device }\end{array}$ & $\begin{array}{c}\text { Upload of the } \\
\text { session video } \\
\text { by the student } \\
\text { to the channel } \\
\text { created on } \\
\text { YouTube }\end{array}$ & $\begin{array}{c}\text { Analysis of } \\
\text { session in } \\
\text { groups of three } \\
\text { and rise of short } \\
\text { video with } \\
\text { reflections }\end{array}$ & $\begin{array}{c}\text { Delivery of the } \\
\text { report of the } \\
\text { student to the } \\
\text { teacher with his } \\
\text { impressions } \\
\text { after the } \\
\text { evaluation of } \\
\text { the teacher and } \\
\text { classmates }\end{array}$ \\
\hline Day zero & $\begin{array}{c}\text { Immediately at } \\
\text { the end of the } \\
\text { session }\end{array}$ & 24 hours & 5 days & 10 days \\
\hline
\end{tabular}

\section{Results and Discussions}

In the implementation phase linked to evaluation, this is articulated from a double perspective: the evaluation of the student's experience and evaluation. The student's evaluation is done using the Socrative mobile application (already defined in the Methodology section) with the validated questionnaire REATIC (De Moya, et al., 2011).

The evaluation of the experience indicates that $84.3 \%$ of students have found it useful to upload videos to a YouTube channel. 17.6\% have learned from this experience to download and edit YouTube videos. In this sense, $41.2 \%$ of the students did not know how to edit videos before and after the didactic experience they are able to do it. Finally, 85.3\% of the students would not have preferred to do a written work on the subject rather than carrying out their own video to analyze the intervention in physical education.

The evaluation of the student, based on the final report that he / she must deliver around his / her teaching intervention, will use the following evaluation 
criteria:

- Be able to differentiate the elements that form the teacher interaction, as well as their importance.

- Collect the impressions of colleagues (through their interventions in the forum in video format), admitting their suggestions or refuting their approaches in a justified and reasoned manner.

- Use quotations and references (at least two) used in class or facilitated as extension resources in the Moodle platform.

- Write in a synthetic and clear way all the previous arguments using no more than 500 words.

\section{Conclusions}

The objectives set were achieved, enriching the contents of the subject through a novel and necessary format to acquire some skills of the teachers in the future schools.

The integration of didactic experiences like this one in university teaching are necessary to extend and improve the methodologies used as the digital competences of the students.

\section{References}

1. ADELL, J., \& BERNABÉ, Y. (2007). Software libre en educación. Tecnología educativa, Madrid: MCGRAW-HILL, 173-195;

2. ANGUERA, M.T. (2004). Hacia la búsqueda de estructuras regulares en la observación del fútbol: detección de patrones temporales, CCD, Cultura_Ciencia_Deporte, 1(1): 15-20, Spain;

3. ANGUERA, M.T., \& HERNÁNDEZ-MENDO, A. (2015). Técnicas de análisis en estudios observacionales en ciencias del deporte, Cuadernos de Psicología del Deporte, 15(1): 13-30. Spain;

4. AREA-MOREIRA, M., HERNÁNDEZ-RIVERO, V., \& SOSA-ALONSO, J. J. (2016). Modelos de integración didáctica de las TIC en el aula, Revista Comunicar, 47(XXIV): 79-87, Spain;

5. ARGILAGA, M.T.A., VILLASEÑOR, A.B., MENDO, A.H., \& LÓPEZ, J. L.L. (2011). Diseños observacionales: ajuste y aplicación en psicología del deporte, Cuadernos de psicología del deporte, 11(2): 63-76, Spain;

6. ARGILAGA, M.T.A., \& ANGUERA, M.T. (1999). Observación en deporte y conducta cinésico-motriz: aplicaciones, Barcelona: Universitat Barcelona, Spain;

7. CARRERA, F.X., \& COIDURAS, J.L. (2012). Identificación de la competencia digital del profesor universitario: un estudio exploratorio en el ámbito de las Ciencias Sociales, REDU: Revista de docencia universitaria, 10(2): 273-298. Spain;

8. CASTAÑEDA, L. (2009). Educación superior y YouTube, Chasqui: Revista latinoamericana de educación, 106: 76-81, Spain;

9. CEBRIÁN, M. (2006). Enseñanza virtual para la innovación universitaria, $2^{\mathrm{a}}$ ed, Madrid: Narcea, Spain; 
10. CHAVARRÍA, J.V. (2011). Software libre, alternativa tecnológica para la educación, Revista Actualidades Investigativas en Educación, 5(2), Spain;

11. DE MOYA, M.V., HERNÁNDEZ, J.R., HERNÁNDEZ, J.A., \& CÓZAR, R. (2011). Análisis de los estilos de aprendizaje y las TIC en la formación personal del alumnado universitario a través del cuestionario REATIC, Revista de Investigación Educativa, 29 (1): 137-156, Spain;

12. ESTEVE, F., \& GISBERT, M. (2011). El nuevo paradigma de aprendizaje y las nuevas tecnologías, REDU: Revista de docencia universitaria, 9(3): 55-83;

13. GARCÍA, A.M.D., \& CUELLO, R.O. (2007). La promoción del uso del software libre por parte de las universidades, Revista de Educación a Distancia, (17), Spain;

14. MARIÑO, J.C.G. (2006). B-Learning utilizando software libre, una alternativa viable en Educación Superior, Revista complutense de Educación, 17(1): 121-133, Spain;

15. MEDINA, J., \& DELGADO, M.A. (2010). Metodología de entrenamiento de observadores para investigaciones sobre educación física y deporte en las que se utilice como método la observación, European Journal of Human Movement, 5: 69-86, Spain;

16. PRADAS, F., BATALLER, V., \& CASTELLAR, C. (2011). La utilización de software libre y la incorporación de tecnología de imagen digital para el aprendizaje de la biomecánica deportiva, In Prácticas y modelos innovadores para la mejora y calidad de la docencia / coord. por Javier Paricio, Ana Isabel Allueva, Prensas Universitarias de Zaragoza, 459-468, Spain;

17. RÍOS, J., \& RUIZ, P. (2011). Competencias, TIC e Innovación. Nuevos escenarios para nuevos retos, Sevilla: MAD- Eduforma, Spain;

18. SALINAS, J. (2012). I uploaded a @YouTube video: Una nueva perspectiva de la televisión educativa, Edmetic: Revista de educación mediática y TIC, 1(1): 7-28, Spain;

19. SANTIAGO, R., AMO, D., \& DÍEZ, A. (2014). Pueden las aplicaciones educativas de los dispositivos móviles ayudar al desarrollo de las inteligencias múltiples, EDUTEC: Revista electrónica de tecnología educativa, 47, Spain;

20. ZABALZA, M.A. (2003). Innovación en la enseñanza universitaria, Contextos Educativos, 6-7: 113-136, Spain;

21. ZABALZA, M.A. (2007). Competencias docentes del profesorado universitario. Calidad y desarrollo professional, $2^{\mathrm{a}}$ ed, Madrid: Narcea, Spain. 